\title{
Baker Island
}

National Cancer Institute

\section{Source}

National Cancer Institute. Baker Island. NCI Thesaurus. Code C123742.

An atoll in the North Pacific Ocean, about halfway between Hawaii and Australia. 